\title{
Facilitating Cooperative Learning In Online and Blended Courses: An Example from an Integrated Marketing Communications Course
}

Katryna Johnson, Ph.D., Metropolitan State University, Minneapolis, USA

\begin{abstract}
Employers today expect that students will be able to work in teams. Cooperative learning theory addresses how skills such as decision making, problem solving and communication can be learned by individuals in group settings. This paper discusses how cooperative learning can be used in an online and blended environment to increase active learning for students. Strategies to enhance collaboration in the online environment are discussed. The use of online discussions, blogs and experiential learning through an undergraduate integrated marketing communications plan are provided as examples of cooperative learning in online and blended environments.
\end{abstract}

Keywords: Cooperative Learning; Online Learning; Instructional Methods; Active Learning; Experiential Learning

\section{INTRODUCTION}

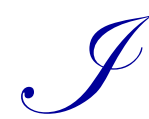

$\mathrm{n}$ the fall of 2012, more than one third of all students took at least one of their courses online (Ebersole, 2012). Online learning can occur in a synchronous (real time) or asynchronous (at student's convenience) environment. In synchronous online learning chat rooms are used for students and instructors to engage in discussions about course content and projects. Asynchronous discussions allow students and instructors access to discussion forums $24 / 7$.

In blended courses, instructors have the opportunity to meet students face-to-face which enhances the personal connection with students. In an online course, the connection must be established through course design and discussions (Brindley, Walti, C. \& Blaschke, 2009; Bruffee, 1995, Siemens 2002, Poole 2000). The connection with students and amongst students needs to be established early in a course in order for collaborative learning to occur (Brindley, Walti, C. \& Blaschke, 2009; Bruffee, 1995, Kop \& Hill, 2008; Siemens 2005). While students appreciate the freedom and flexibility that online courses offer, they also desire guidance in the resources and activities needed to critically engage them in course content (Kop \& Hill, 2008; Palloff \& Pratt, 2005). Instructors can provide such opportunities through cooperative learning experiences.

\section{COOPERATIVE LEARNING: A TEAM BASED APPROACH}

Cooperative learning is a team based activity in which students work together to accomplish a goal (Brindley, Walti \& Blaschke 2009; Bruffee, 1995; Panitz, 2001). Cooperative learning provides a structured process to working in teams (Johnson, Johnson \& Smith, 1991; Millis \& Cotrel, 1998). Cooperative learning provides opportunities for students to engage in critical thinking by interacting with other students to discuss and elaborate on their ideas (Bonwell \& Eison, 1991; Johnson, Johnson \& Smith, 1991).

Johnson, Johnson \& Smith (1991) describe five elements needed for successful cooperative learning: (a) positive interdependence, where the group has a common goal; (b) promotive interaction, where individuals commit to helping others learn; (c) individual and group accountability, where members divide the work and are assigned 
specific responsibilities; (d) interpersonal and small group skills, where individuals make decisions, resolve conflicts and effectively communicate and; (e) group processing, where students reflect on their experience.

Strategies that can be used to increase cooperative learning in a course include forming small teams ( 3 to 4 students), setting clear expectations for assignments, identifying specific roles or jobs for team members, establishing norms of behavior early on, specify how team members should communicate and using what tools (e.g. wikis, discussion forums), defining how frequently team members should communicate with each other, providing for team reflections and evaluations, discussing how the team should communicate with the instructor, giving feedback, facilitating group formation, and providing sufficient time for tasks (Brindley, Walti, \& Blaschke, 2009; Fleming, 2008; Gradel \& Edson 2010-2011; Millis \& Cottell, 1998; Strong \& Anderson 1990; Wichadee, \& Orawiwantakul, 2012). Free riders or social loafers in teams can be a source of particular frustration to students (Strong \& Anderson, 1990). While students can give feedback on team evaluations, having a process in place such as allowing members to "divorce" themselves from a group has been found to have a strong effect on decreasing free riders (Strong \& Anderson, 1990; Bacon Steward, Silver, 1999; Strong \& Anderson, 1990).

\section{Collaborative Learning in the Online Environment}

In the online environment, collaborative learning allows students to develop skills they can apply in the job setting such as coordinating across time zones and geographic locations, developing computer skills, enhancing internet search skills, and interacting with individuals from diverse backgrounds (Narzony, 2010). Online learning may occur through many venues such as discussions, forums, videos, wikis, blogs, podcasts and other online objects (Campbell \& Ellingson, 2008; Fleming, 2008; Gradel \& Edson, 2010-2011; Lynch, 2010; Pallof \& Pratt; 2005; Pentina, 2010; Weber, 2008). The advantage to students is the opportunity to participate in a variety of activities that can engage them in the learning experience (Bonwell \& Eison, 1991; Hagan, 2012; Kolb 1984; Weber \& Lennon, 2007). In an online environment the instructor's forethought to the predesign of the course and how teams communicate is essential to successful collaboration (Fleming 2008; Palloff \& Pratt 2005).

Many instructors use discussion for collaborative learning (Fleming, 2008; Lynch 2010; Poole, 2000). Instructors need to be able to create good online discussion questions. The questions need to be well-planned with forethought to the outcome (Fleming, 2008; Gradel \& Edson 2010-2011). Discussion questions should incorporate class content, projects and other material into the discussion to make the discussions relevant and to motivate students (Fleming, 2008; Gradel \& Edson 2010-2011). Interactivity amongst students and with the instructor varies in quality and quantity (Swan, 2001). Consistent with the pedagogy of collaborative learning Poole (2000) found that students engaged in reflection in their class discussions. Swan (2001) found that students who interacted more in discussions with other students and their instructor reported higher levels of satisfaction and higher levels of learning from peers and the course.

Other research examines the use of Wikis which allow users to quickly create and share information (Bold, 2006; Campbell \& Ellingson, 2010; Chang, Morales-Arroyo, Than, Tun, \& Wang, 2010-2011; Su, \& Beaumont, 2010; Weber, 2008; Witney \& Smallbone, 2011). Wikis allow students to interact and collaborate on course assignments and projects outside of the classroom. Wikis can be set up within content management servers such as Blackboard or through the Internet on sites such as MediaWiki.org. Many studies find that wikis create a positive environment for collaboration as they allow students to easily store and edit information (Campbell \& Ellingson, 2010; Chang et. al, 2010-2011; Weber, 2008; Witney \& Smallbone, 2011). Chang et. al. (2010-2011) found that wikis were helpful in supporting collaborative writing, facilitating a supportive environment for the team, helping team members to assess the progress of group's work and promoting accountability in the group. Students also note that they like options for communication while being at a distance (Chang et. al. 2010-2011). However, in one study some students have noted that they found wikis confusing (Su \& Beaumont, 2010). Additionally, half the students in one study noted concern over expressing their ideas on an internet wiki or that someone might change the work they had done (Su \& Beaumont, 2010) and half the students in a different studied expressed a negative reaction if the use of a wiki was required for a course (Witney \& Smallbone, 2011).

Instructors also use team projects to facilitate collaboration (Hanson, 2006; Olivera, Tinoca, \& Pereira, 2011; Scherling, 2011; Williams, Morgan \& Cameron, 2011). Group projects allow students to develop skills time 
management, decision making and problem solving and critical thinking (Bonwell \& Eison, 1991; Kolb, 1984). Employers also have the expectation that students will be able to work in teams on real world problems (Benajmin \& O'Reilly, 2011; Hanson, 2006). Instructors need to consider the breadth of the project in allotting as much time as possible for students to coordinate their work, groups need to establish norms before beginning the project, deadlines should be given, teammates should be required to provide feedback and allowed to evaluate each other, and progress should be monitored (Bacon, Steward, Silver, 1999; Scherling, 2011; Strong \& Anderson 1990).

\section{EXPERIENTIAL LEARNING IN THE CLASSROOM}

Instructors and students today expect to be actively engaged in the classroom (Bonwell \& Eison, 1991; Kolb, 1984). Active learning requires students to be more than passive recipients of knowledge; it involves them in the material by involving students in case studies, projects, and reflective activities that synthesize knowledge and practical applications (Bonwell \& Eison, 1991; Kolb, 1984). Instructors have used case studies, situation analysis, small group discussions, simulations, personal response systems, think-pair-share activities, and client projects to successfully engage students in active cooperative learning activities (Cavanagh, 2011; Laverie, 2006; Lightner, Marcie \& Willi, 2007; Munoz \& Huser, 2008, Pentina, 2010).

\section{IMPLEMENTING AN INTEGRATED MARKETING COMMUNICATIONS PLAN}

Students in an undergraduate Integrated Marketing Communications course frequently take on a role of an advertising agency to develop an Integrated Marketing Communications (IMC) plan that includes researching information on the company, its products, consumers, competitors and its current forms of advertising and promotions. Working in teams of three to four members students develop an IMC plan. The goals of the plan include:

- $\quad$ Using secondary research on the university databases and through the Internet to create a situation analysis.

- Developing an accurate positioning statement.

- $\quad$ Preparing a creative brief.

- $\quad$ Selecting media and creating media executions.

- Understanding evaluation tools for media campaigns

Students are provided with a variety of tools for accomplishing the IMC plan. Students have access to the content management server D2L where they have class discussion forums, group lockers for sharing files, group discussion areas, and examples of previous IMC plans and team charters.

\section{Discussions}

Students in both blended and online courses begin with introductory discussions the first two weeks of class to establish familiarity with each other. The question asks students to list their major, three strengths, three weaknesses and three products they might like to work on for the IMC plan for the semester. This discussion allows students in the fully online class to learn about each other and see who has common interests in the first week.

A discussion forum is set up for students for forming teams. The instructor tracks the potential ideas that students has listed and lists the possible ideas in this forum. This quickly allows students to search for possible teammates for the IMC plan.

\section{WordPress.com and LinkedIn.com}

During the first two weeks of class students are provided with information to set up a WordPress.com account. The instructor has a WordPress.com account for the course with images, links, videos and reblogs to show students some of the basics of the blog site (Figure 1). Students are encouraged to join LinkedIn not only to network but also to promote their WordPress.com site after they have worked on their blog for several weeks (see Figure 2 for details in the schedule in the team charter). Since research findings have indicated that students appreciate flexibility in how they collaborate (Witney \& Smallbone 2011), the use of WordPress is provided as an option for 
students. WordPress.com allows students to express creativity in what they are learning in the course, their IMC plans, brands and their ideas. While many have familiarity with social networking sites such as Facebook and Twitter, WordPress allows them to not only interact with each other but to receive feedback from individuals outside of the classroom.

\section{Figure 1}

WordPress.com offers images, links and other information you might find helpful to your project. On WordPress you will be able to upload images, videos, links and reblog posts that you wish to share about your course project. You can look at the WordPress.com site for the course as an example. If you wish to create a WordPress blog, please post the URL to the discussion forum for WordPress.com so that it is available for all class members to visit.

Please also join LinkedIn.com. You can join groups to help build your network in social media and marketing communications and later promote your blog to get feedback from experts in the field of marketing communications.

\section{Team Charter}

Teams are asked to fill in a team charter where students where students assign responsibilities for the project to individual members and provide deadlines for all assignments. Previous student examples of charters are also provided to students. Information is provided to students in the syllabus about "divorcing" from a group. Students submit the charter to the instructor during the fourth week of class for points. An abbreviated team charter is provided in Figure 2. The team charter is an essential tool for establishing the roles each student will play in the team, and the responsibilities they will assume. Formal team evaluations occur two times during the semester allowing students to hold each other accountable for their work. Informal evaluations take place in the blended class during small group discussions.

\section{Figure 2}

\section{Abbreviated Team Charter}

The key to writing the charter is to assign responsibilities to team members for project and to set deadlines.

\begin{tabular}{|l|l|l|}
\hline Name & Email & Telephone \\
\hline Name 1 & Name 1@ & $111-1111$ \\
\hline Name 2 & Name 2@ & $222-2222$ \\
\hline Name 3 & Name 3@ & $333-3333$ \\
\hline
\end{tabular}

\section{Possible Team Norms}

- Members are to encourage each other to submit ideas to the group.

- Members are to be courteous and respectful when giving feedback.

- Members are to bring up any questions or concerns to the group in a timely manner so it can be handled in an appropriate amount of time.

- $\quad$ The work must be divided in an equal manner (see schedule for individual responsibilities).

- The work must be submitted through the group discussion topic on D2L be the designated time (see schedule).

- A designated member of the team will then take all sections of the project and combine them into a cohesive group. The member will then post it to D2L so the team will then have time to read through it and request any changes if necessary.

- All members are required to actively participate on the D2L discussion board and through emails with group members.

- All members must check into the discussion forum at least three times a week.

\section{Team Evaluations}

Team members will formally evaluate peers when the situation analysis and the final paper are submitted. These evaluations may influence the final grade of the paper. Team evaluations will be based on meeting deadlines, maintaining rapport with the team, submitting high quality work, providing feedback in a timely manner, offering constructive feedback, demonstrating critical thinking in work, showing respect, performing one's "fair share" of the work for the project. 


\begin{abstract}
Team Sanctions
If any team chooses to "divorce" a member, this must be done in writing at least one week before an assignment is due and an email needs to be sent to the instructor and the team member.

- $\quad$ Groups can divorce a team member for not contributing to an assignment (including discussions).

- All group members must agree to the divorce of a group member.

- A group member can be reinstated at any time with consensus from the entire group.

- If the group member is divorced, the group member forfeits/receives a zero on all future group work. The group member can try to find another group or can work individually on the project for the rest of the semester.
\end{abstract}

\title{
SCHEDULE
}

\section{Group Discussion}

The discussions will be divided as follows:

Week 6: Student A

Initial posting to group discussion board: $9 / 26$ by $11: 00 \mathrm{pm}$

Group members are allowed to edit until 9/28 11:00pm

Student A must have edited discussion posted no later than $9 / 29$ at 11:00pm

Week 10: Student B

Initial posting to group discussion board: $10 / 24$ by $11: 00 \mathrm{pm}$

Group members are allowed to edit until 10/26 11:00pm

Student B must have edited discussion posted no later than 10/27 at 11:00pm

Week 12: Student C

Initial posting to group discussion board: $11 / 7$ by $11: 00 \mathrm{pm}$

Group members are allowed to edit until 11/9 11:00pm

Student C must have edited discussion posted no later than 11/10 at 11:00pm

\section{WordPress \& LinkedIn}

Week 5 Students Create WordPress Account and make initial post.

All students create LinkedIn Accounts. Students share WordPress URL with each other.

Week 7 Upload Photo to WordPress

Week 9 Upload Video Link to WordPress

Week 10 Reblog a post

Week 12 Make a post

Week 13 Promote blog on LinkedIn

\section{Written IMC Plan}

Week7 Situation Analysis Sections I and II - due 10/23

Industry Analysis -Student A

Company Background -Student B

Product/Brand Information -Student $\mathrm{C}$

Customer/Buyer Analysis -Student A

Competition -Student B

SWOT Table and Discussion - Student C

Current Marketing Mix - Student A

Current/Past Promotion Programs - Student B

Week 13 Creative Strategy- due 11/20

Positioning - Student C

Creative Brief -Student C

Media and Creative Executions

Social Media - Student A, B \& C

Advertising - Student C

Print - Student A

Outdoor - Student B

Sales Promotions- Student B

Campaign Evaluation-Student $\mathrm{C}$ 


\section{Reflection Paper}

During the last week of class students write a reflection paper on their experiences about the class and the project. The paper is open to their interpretation of what the experience meant to them. Student comments on the experience include:

- $\quad$ I like how interactive all the students were with the suggestions on our large group projects.

- I also was able to learn time management skills from this class. Time management skills and proper communication were critical to the success of this class.

- $\quad$ I enjoyed working on the IMC campaign project. It was interesting to take a struggling company and really break it down from where they were, where they are, and where, with our help could be going. It made me feel like I was doing real world work in the industry and got to use a lot of creativity in the second half of the project. It was an actual applicable assignment preparing me for what I may encounter in the future when seeking employment.

Students perspectives on collaborating in general has been positive, but have varied with individual personalities and if group conflict occurred. Having a team charter in place for accountability and allowing for "divorce" from a group can assist with group conflict (Strong \& Anderson, 1991). In the work world, and in the world of advertising, being able to work on a team is essential, and students in an IMC class have the project positioned as a real experience of creating a working project. Guest speakers from advertising agencies in the blended classes reinforce the team concept each semester and students in the blended classes due tend to have slightly more positive outlooks on collaborating if not only because of the time in class for promotive interaction, but also the chance to interact with the guest speakers. (These speakers are videotaped for the online class).

In reflection papers, in class and in discussions students have mentioned using other forms of communication to facilitate their progress in collaboration such as Moodle or Google Docs and this is always encouraged by the instructor.

\section{CONCLUSION}

Taking time to predesign a course, set up processes for student groups for communication and coordination, and clarifying assignments and expectations greatly facilitates cooperative learning as it allows students to assign responsibilities, tasks and deadlines to individual members. A critical component to the cooperative learning process is students receiving feedback amongst their group and receiving feedback to the instructor about the progress of the teams. Ensuring that students can communicate with each other about the progress of a project and with the instructor will greatly impact a successful completion of an online project.

\section{AUTHOR INFORMATION}

Katryna M. Johnson, Ph.D. is Associate Professor of Marketing at Metropolitan State University, Minneapolis, Minnesota. She teaches courses in Consumer and Professional Buyer Behavior, Integrated Marketing Communications, Marketing Management, and Practical Research Methods for Managers. She earned her Ph.D. from Carlson School of Management, University of Minnesota. E-mail: Katryna.johnson@ metrostate.edu

\section{REFERENCES}

1. Bacon, D. R., Steward, K. A., Silver, W. S. (1999). Lessons from the best and worst student team experiences: How a teacher can make the difference. Journal of Management Education, 23(5) 467-488.

2. Benjamin, B. \& O'Reilly, C. (2011), Becoming a leader: Early career challenges, faced by MBA graduates, Academy of Management Learning \& Education, 10(3), 452-472. DOI: 10.1177/105256299902300503

3. Bold, M. (2006). Use of wikis in graduate course work. Journal of Interactive Learning Research, 17 (1), 5-14.

4. Bonwell, C. \& Eison, J. (1991). Active Learning: Creating Excitement in the Classroom AEHE-ERIC Higher Education Report No. 1. Washington, D.C.: Jossey-Bass. 
5. Brindley, J.E., Walti, C. \& Blaschke, L.M. (2009, June). Creating effective collaborative learning groups in an online environment. International Review of Research in Open and Distance Learning, 10(3), 1-18.

6. Bruffee, K. A. (1995). Sharing our toys: Cooperative learning versus collaborative learning. Change, 27 , 12-18, DOI: 10.1080/00091383.1995.9937722

7. Campbell, K. \& Ellingson, D.A. (2010). Cooperative learning at a distance: An experiment with wikis. American Journal of Business Education, 3(4), 83-89.

8. Cavanagh, M. (2011). Students' experiences of active engagement through cooperative learning activities in lectures. Active Learning in Higher Education, 12(1), 23-33. DOI: 10.1177/1469787410387724

9. Chang, Y., Morales-Arroyo, M. A., Than, H., Tun, Z., \& Wang, Z. (2010/2011). Collaborative learning in wikis. Education for Information, 28(2-4), 291-303.

10. Ebersole, J. (2012, August 24). The myths of online learning. Forbes, retrieved from http://www.forbes.com/sites/johnebersole/2012/08/24/the-myths-of-online-learning/

11. Fleming, D.L. (2008). Using best practices in online discussion and assessment to enhance collaborative learning. College Teaching Methods \& Styles Journal, 4(10), 21- 39.

12. Gradel, K., \& Edison, A.J. (2010-2011). Cooperative learning: Smart pedagogy and tools for online and hybrid courses. Journal of Educational Technology Systems, 39(2), 193-212. DOI: 10.2190/ET.39.2.i.

13. Hagan, L.M. (2012). Fostering experiential learning and service through client projects in graduate business courses offered online. American Journal of Business Education, 8 (12), 623-632.

14. Hanson, R.S. (2006). Benefits and problems with student teams: Suggestions for improving team projects. Journal of Education for Business, 82(1), 11-19.

15. Johnson, D.W., Johnson, R.T., Smith, K.A. (1991). Active learning: Cooperation in the college classroom. Interaction Book Co: Edina, MN.

16. Kolb, D. (1984). Experiential learning: Experience as the source of learning and development. Englewood cliffs, NJ, Prentice Hall.

17. Kop, R., \& Hill, A. (2008). Connectivism: Learning theory of the future or vestige of the past? International Review of Research in Open and Distance Learning, 9(3), 1-13.

18. Laverie, D. A. (2006), In-class cooperative learning: a way to build knowledge and skills in marketing courses. Marketing Education Review, 16, 59-76.

19. Lightner, S., Marcie, J.B., \& Willi, C. (2007). Team-based activities to promote engaged learning. College Teaching, 55 (1) 5-18. DOI: 10.1177/1046878108325713

20. Lynch, D.J. (2010). Application of online discussion and cooperative learning strategies to online and blended college courses. College Student Journal, 44, 777-784.

21. Millis, B.J. \& Cotrel, P.G. (1998). Cooperative Learning for Higher Education Faculty. Phoenix, AZ: Oryx.

22. Munoz, C. \& Huser, A. (2008). Experiential and cooperative learning: Using a situation analysis project in principles of marketing. Journal of Education for Business, 83(4), 214-220.

23. Narozny, E. (2010, May 19). Designing online courses to meet the needs of a diverse student population. faculty focus: Focuses on today's higher education professional, Retrieved from

http://www.facultyfocus.com/articles/online-education/designing-online-courses-to-meet-the-needs-of-adiverse-student-population/

24. Olivera, I., Tinoca, L., \& Pereira, A. (2011). Online group work patterns: How to promote a successful collaboration. Computers \& Education, 57(1), 1348-1357.

25. Palloff, R. M. \& Pratt, K. (2005). Collaborating Online: Learning Together in Community. San Francisco, CA: Jossey-Bass.

26. Panitz, T. (2001). Collaborative versus cooperative learning: A comparison of the two concepts which will help us understand the underlying nature of interactive learning. Retrieved from http://home.capecod.net/ tpanitz/tedsarticles/coopdefinition.htm

27. Pentina, I. (2010). Using social media to address curriculum objectives in integrated marketing communications course. Journal for Advancement of Marketing Education, 17, 104-111.

28. Poole, D. M. (2000). Student participation in a discussion-oriented online course: A case study. Journal of Research Computing in Education, 33(2) 162-169.

29. Scherling, S. (2011). Designing and fostering effective online group projects. Adult learning, 22, 13-18. 
30. Siemens, G. (2005). Connectivism: Learning theory for the digital age. International Journal of Instructional Technology and distance learning, 2(1), Retrieved from http://www.itdl.org/Journal/Jan_05/article01.htm

31. Siemens, G. (2002). Interaction. E-Learning Course. Retrieved from http://www.elearnspace.org/Articles/Interaction.htm

32. Strong, J.T. \& Anderson, R.E. (1990). Free-riding in group projects: Control mechanisms and preliminary data. Journal of Marketing Education, 12, 61-67.

33. Su, F. \& Beaumont, C. (2010). Evaluating the use of a wiki for collaborative learning. Innovations in Education \& Teaching International. 47(4), 417-431, DOI: 10.1080/14703297.2010.518428.

34. Swan, K. (2001). Virtual interaction: Design factors affecting student satisfaction and perceived learning in asynchronous online courses. Distance Education, 22(2), 306-331.

35. Weber, J.M. (2008). The comparison and testing of a hybrid wiki course. Journal of Advancement in Marketing Education, 13, 41-46.

36. Weber, J.M. \& Lenon, R. (2007). Multi-course comparison of traditional versus web-based course delivery systems. The Journal of Educators Online, 4(2), 1-19.

37. Wichadee, S. \& Orawiwantakul, W. (2012, Second Quarter). Cooperative language learning: Increasing opportunities for learning teams. Journal of College Teaching \& Learning, 9 (2), 93-100.

38. Williams, K. C., Morgan, K., Cameron, B.A, (2011). How do students define their roles and responsibilities in online learning group projects. Distance Education, 32 (1), 49-62.

39. Witney, D. \& Smallbone, T. (2011). Wiki work: Can using wikis enhance student collaboration for group assignment tasks? Innovations in Education \& Teaching International. 48 (1), 101-110. 